\title{
A Comparison of Economic Efficiency of Monoculture and Multiple Cropping Patterns: The Case of Cassava Farming in Ende, Indonesia
}

\author{
Willybrordus Lanamana* and Philipus Nerius Supardi \\ Faculty of Agriculture, Universitas Flores, Ende, Indonesia \\ *Corresponding author: wlanamana@yahoo.com
}

\begin{abstract}
Nuabosi cassava is an alternative carbohydrate source for the community, which is expected to be a substitute for rice. This commodity has the potential to be developed, but is limited in resources, so it requires technological breakthroughs. This study aims at analyzing the level of technical, allocative and economic efficiency between the cassava cropping pattern and the factors that affect the efficiency. The research was conducted in Randotonda Village, from November 2019 to January 2020 and the samples consisted of 61 monoculture farmers and 46 multiple cropping farmers. Data analysis was performed using the Cobb-Douglass stochastic frontier production function. The allocative and economic efficiency was examined with the stochastic frontier cost function approach. The results of stochastic frontier estimation show that all variables have a positive effect on the production variable. The variables having a positive effect on the total cost include the price of cassava cuttings, the price of fertilizer, production and the dummy cropping pattern. The average level of economic efficiency of monoculture farmers is lower than that of multiple cropping farmers. Factors that affect economic efficiency are age, length of time to cultivate, frequency of obtaining information, dummy of farmer group membership and dummy of cropping patterns. In short, the level of technical, allocative and economic efficiency of monoculture farmers is lower than that of multiple cropping farmers. Farmers are expected to pay attention to the types of plants that are suitable in implementing the multiple cropping pattern.
\end{abstract}

Keywords: cassava multiple cropping; economic efficiency; frontier production function

Cite this as: Lanamana, W., \& Supardi, P. N. (2021). A Comparison of Economic Efficiency of Monoculture and Multiple Cropping Patterns: The Case of Cassava Farming in Ende, Indonesia. Caraka Tani: Journal of Sustainable Agriculture, 36(1), 69-82. doi: http://dx.doi.org/10.20961/carakatani.v36i1.41784

\section{INTRODUCTION}

Human civilization is currently faced with serious food scarcity. The global food stock base of cereals has experienced a crisis due to climate change in recent years. However, the lifestyle of modern society prefers food from cereals and seeds (FAO, IFAD and WFP, 2013). The wealth of biodiversity must be preserved and used optimally to fulfill the need of food for present and future generations. Food is not only based on cereals and seeds but also takes form of root crops, especially cassava. This plant has wide adaptability to tropical areas and the main food source for ancient civilizations (Widodo, 2018).

The productivity of cassava in India in 2013 reached 35 tons ha ${ }^{-1}$ (FAO, IFAD and WFP, 2013). In Indonesia, it only reached 22.48 tons ha $^{-1}$ in 2017 and 24.4 tons ha ${ }^{-1}$ in 2018 (Widodo, 2018). The productivity of cassava in the 20152018 period fluctuated quite a bit with a downward trend. This was indicated by a decrease in the harvested areas each year with an average annual growth of $3.36 \%$ (BPS, 2018). The problems of low productivity were quite diverse,

\footnotetext{
* Received for publication May 25, 2020

Accepted after corrections October 31, 2020
} 
namely, the utilization of less superior varieties, late fertilizing, the amount of fertilizers given and limited irrigation facilities.

The contribution of cassava to the Gross Regional Domestic Product (GRDP) of Ende Regency in the food crop sub-sector ranks at the first place. This commodity is expected to be an alternative source for the community; however, the productivity of cassava in Ende is relatively lower, with 12 tons $\mathrm{ha}^{-1}$ in 2016 (BPS - Statistics of Ende Regency, 2016), when compared to the national productivity. This was allegedly due to the use of production technology and the price received, which was not as an incentive for farmers to continue planting cassava. This phenomenon was also found in Randotonda Village. The interviews with field extension officers and the head of the village have revealed that the productivity of Nuabosi cassava in 2020 only reached 17.50 tons $\mathrm{ha}^{-1}$, which was due to reduced land area and relatively low selling price of IDR 7,000 $\mathrm{kg}^{-1}$ at the farmer level. Cultivation technology was also carried out conventionally without fertilization. Chepng'etich et al. (2015) argues that small-scale agricultural systems are usually characterized by limited resources. Improving technical efficiency in resourcelimited small-scale agricultural systems is key to increase household food availability (Itam et al., 2015).

Nuabosi cassava is the district's leading commodity because it has several advantages, which among others are productivity and high quality, delicious taste, soft texture and low levels of hydrogen cyanide $(\mathrm{HCN})$. Based on these advantages, the cassava is necessary to be developed by applying the technology of multiple cropping with peanuts, where planting is carried out at the same time. Nyi et al. (2014) suggest that planting cassava together with peanuts can increase productivity and profit. Ajieh et al. (2014) also assert that technology adoption will increase production and affect income.

The application of multiple cropping pattern is an inevitable option in a sustainable agricultural system, which is oriented towards three sustainable dimensions, namely natural ecology, economic enterprises and human social life (Rivai and Anugrah, 2011). Multiple cropping of cassava and peanuts can minimize the use of inorganic fertilizers. Farmers can use peanut waste as organic fertilizer. Cassava and peanut multiple cropping can improve soil quality by increasing the nitrogen content in the soil (Tang et al., 2020). With this pattern, the economic benefits for farmers are higher, for they get income from both cassava and peanuts (Hongxin et al., 2016).

One way to increase food crop production is by practicing multiple cropping pattern (Sasmita et al., 2014). Combining cassava and peanuts can help control weeds (Amosun and AduramighaModupe, 2016). Multiple cropping can increase per-unit farmland productivity through a resource-efficient utilization (Chen et al., 2019). Multiple cropping of corn and peanuts can provide benefits and increase land productivity (Li et al., 2019). Some of the studies above show that multiple cropping patterns support sustainable agricultural systems in the tropics.

Increasing production through technical, allocative and economic efficiency is very important because it can multiply the potential output of farmers and reduce farming costs (Kusnadi et al., 2011). Efficiency can improve output without having to add input and the level of efficiency is influenced by socio-economic factors (Ogundari and Brümmer, 2011). Studies on efficiency have received much attention, including from Khan and Saeed (2011); Adem and Gebregziabher (2014); Latruffe and Nauges (2014) and Galluzzo (2017), with some variations in methodology, data type, model specification and location. These studies are very helpful in analyzing the level of efficiency between the planting patterns of Nuabosi's cassava commodities in small farmers, who have mutual cooperation with local wisdom, with increasingly limited land areas, so a technological breakthrough is needed. The present study provides an answer to the idea of food diversification in East Nusa Tenggara Province, because cassava is one of the main food substitutes for rice. The study examines the level of technical, allocative and economic efficiency between the cassava cropping pattern and the factors that affect the efficiency.

\section{MATERIALS AND METHOD}

The research was conducted in Randotonda Village, Ende Sub-district, Ende Regency, in East Nusa Tenggara Province of Indonesia, from November 2019 to January 2020. The research location was determined with the following considerations: (a) it is a Nuabosi cassava 
cultivation center and (b) there are many farmers practicing multiple cropping pattern of cassava and peanuts. The population in this study were all of the Nuabosi cassava farmers in Randotonda Village, amounting to 210 people. A total of 119 applied monoculture farming and 99 farmers practiced multiple cropping of cassava and peanuts. Cluster sampling was employed to gather the samples. The calculation of sample size resulted a total of 107 farmers as respondents, comprising 61 monoculture farmers and 46 multiple cropping farmers. The sample size was calculated using the following formula (Parel et al., 1973).

Note:

$$
n=\frac{N Z^{2} \sigma^{2}}{N d^{2}+Z^{2} \sigma^{2}}
$$

$\mathrm{n}=$ Sample size

$\mathrm{N}=$ Population size

$\mathrm{D}=$ Tolerable minimum deviation $=0.05$

$\mathrm{Z}=95 \%$ confidence level $=1.96$ according to $\mathrm{Z}$ distribution table

$\sigma^{2}=$ Population variance in the $\mathrm{V}$ of cassava farming land

The analytical method used in this research was production function analysis of CobbDouglass stochastic frontier. The frontier production model was estimated using MLE (maximum likelihood estimation) and Frontier Version 4.1 software. The production functions were as follows:

$$
\begin{aligned}
\operatorname{Ln} Y= & \beta_{0}+\beta_{1} \operatorname{Ln} X_{1}+\beta_{2} \operatorname{Ln} X_{2}+\beta_{3} \operatorname{Ln} X_{3} \\
& +\beta_{4} \operatorname{Ln} X_{4}+\beta_{5} \operatorname{Ln} X_{5}+E_{j} D_{j}\left(V_{i}-u_{i}\right)
\end{aligned}
$$

Note:

$\mathrm{Y}=$ Production

$\mathrm{X}_{1}=$ Area of land (ha)

$\mathrm{X}_{2}=$ Cassava seed (cutting)

$\mathrm{X}_{3}=$ Fertilizer $(\mathrm{kg})$

$\mathrm{X}_{4}=$ Labor (workers' day)

$\mathrm{X}_{5}=$ Pesticide $(\mathrm{kg})$

$\mathrm{E}_{\mathrm{j}}=$ Dummy variable coefficient

$D_{j}=$ Cropping pattern dummy variable $(D=1$ multiple cropping method, $\mathrm{D}=0$ monoculture)

$\mathrm{Bi}=$ Regression coefficient $(\mathrm{i}=0,1,2, \ldots .5)$

Measurement of technical efficiency of farming production for the $i^{\text {th }}$ farmer was estimated using the following formula:

$$
T E_{i}=\frac{Y_{i}}{Y_{i}^{*}}=\frac{\exp \left(x_{i} \beta+V_{i}-u_{i}\right)}{\exp \left(x_{i} \beta+v_{i}\right)}=\exp \left(-u_{i}\right)
$$

Where $Y_{i}$ was the actual production of the observation and $\mathrm{Y}_{\mathrm{i}}{ }^{*}$ was the frontier production estimation obtained from stochastic frontier production function. Allocative and economic efficiency was analyzed using stochastic frontier cost function approach. The analysis was performed with Frontier Version 4.1 software. The empirical model of Cobb-Douglas stochastic frontier cost function was on the following equation:

$$
\begin{aligned}
\operatorname{Ln} C_{i}= & \alpha_{0}+\alpha_{1} \operatorname{Ln} P x_{1 i}+\alpha_{2} \operatorname{Ln} P x_{2 i} \\
& +\alpha_{3} \operatorname{Ln} P x_{3 i}+\alpha_{4} \operatorname{Ln} Y_{i}+E_{j} D_{j} \\
& +\left(V_{i}+U_{i}\right)
\end{aligned}
$$

Note:

$\mathrm{C}=$ Production cost (IDR)

$\mathrm{X}_{1}=$ Cassava cutting price (IDR kg-1)

$\mathrm{X}_{2}=$ Fertilizer price (IDR kg-1)

$\mathrm{X}_{3}=$ Labor wage (IDR workers' day ${ }^{-1}$ )

$\mathrm{Y}_{\mathrm{i}} \quad=$ Total output $(\mathrm{kg})$

$\mathrm{E}_{\mathrm{j}} \quad=$ Dummy variable coefficient

$\mathrm{D}_{\mathrm{j}} \quad=$ Cropping pattern dummy variable: $\mathrm{D}=1$ multiple cropping; $\mathrm{D}=2$ monoculture

$\mathrm{V}_{\mathrm{i}}+\mathrm{U}_{\mathrm{i}}=$ Error term component

$\mathrm{V}_{\mathrm{i}}=$ Random variable assumed to be independently and identically distributed as $\mu \quad\left(0, \quad \sigma^{2} v\right)$ and independent of $\mathrm{U}_{\mathrm{i}} \mathrm{s}$; that represent the stochastic effect outside the farmer's control

$\mathrm{U}_{\mathrm{i}} \quad=$ One sided $(\mathrm{Ui} \geq 0)$ efficiency component that represents economic inefficiency in production, which is assumed to be independently and identically distributed as truncation (at zero) of the normal distribution with mean, $\mathrm{Ki} \sigma$ and variance

$\alpha=$ Estimated parameter

Cost inefficiency $\left(\mathrm{CE}_{\mathrm{i}}\right)$ wa defined as the ratio between total actual cost $(\mathrm{C})$ and estimated total minimum cost $\left(\mathrm{C}^{*}\right)$, so that $\mathrm{CEi}_{i}$ value ranged between one and infinity. Thus, the inverse of $\mathrm{CE}_{\mathrm{i}}$ was the cost efficiency level. Cost efficiency was defined as allocative efficiency (EA). The EA was formulated as follows: $\mathrm{AE}_{\mathrm{i}}=1 / \mathrm{CE}_{\mathrm{i}}$. The value of EA obtained ranged between 0 and 1 . 


$$
C E_{i}=\frac{C}{C^{*}}=\frac{E(C \mid u i, Y i, P i)}{E\left(C_{i} \mid u i=0, Y i, P i\right)}=\exp (-u i)
$$

To measure the economic efficiency (EE) per individual farmer, the formula of $\mathrm{EE}_{\mathrm{i}}=\mathrm{ET}_{\mathrm{i}}$. $E_{i}$. was used. Factors affecting the level of technical efficiency, EA and EE were estimated simultaneously with the frontier production function using Ordinary Least Square (OLS) method of multiple linear regression model. Linear regression model factors affecting the technical efficiency, EA, EE were formulated as follows:

$$
U_{i}=\delta_{0}+\delta_{0} Z_{1}+\delta_{0} Z_{2}+\delta_{0} Z_{3}+\delta_{0} Z_{4}+\delta_{0} Z_{5}
$$

Note:

$\mathrm{U}_{\mathrm{i}}=$ Technical/allocative/economic efficiency

$\mathrm{Z}_{1}=$ Age

$\mathrm{Z}_{2}=$ Length of farming

$Z_{3}=$ Frequency of getting information

$Z_{4}=$ Dummy of farmer group membership

$\mathrm{Z}_{5}=$ Cropping pattern dummy

\section{RESULTS AND DISCUSSION}

\section{Distribution of technical efficiency level}

The production process is technically efficient if the value of TE $=1$ (full efficiency) (Coelli et al., 2005). In Table 1 , the average level of technical efficiency of farmers with a monoculture cropping pattern is $78 \%$ and it is assumed that there are obstacles in increasing productivity. The average value of technical efficiency means that the average Nuabosi cassava farmers with a monoculture cropping pattern can reach a minimum of $78 \%$ of the production potential obtained from the combination of production inputs used. This finding is in line with that reported by Kitila and Alemu (2014), where the $\mathrm{TE}$ value $<1=66$. If cassava farming with a monoculture cropping pattern per farmer is managed using the best cultivation technology through weed cleaning, using fertilizers and spacing, the production will increase by 8.5 tons. The average actual production is 30 tons $\mathrm{ha}^{-1}$, where the potential production per hectare $=(100: 78) \times 30$ tons $\mathrm{ha}^{-1}=38.5$ tons ha ${ }^{-1}$.

The average level of technical efficiency of farmers with multiple cropping was $86 \%$. This value exemplifies that the average cassava farmers practicing multiple cropping could reach at least $86 \%$ of the potential production from the combination of production inputs. The actual average production was 42 tons $\mathrm{ha}^{-1}$, with potential production per hectare $=(100: 86)$ x 42 tons $\mathrm{ha}^{-1}=49$ tons ha ${ }^{-1}$. If Nuabosi's cassava farming with a multiple cropping pattern is managed properly, through the use of plant sereza as organic fertilizer, cleaning weeds and arranging proper spacing, the production can be increased to 7 tons ha $^{-1}$. The technical efficiency level of farmers with monoculture was lower than that of famers with multiple cropping, due to differences in their knowledge and technical skills of cultivation. The findings of studies by Orewa (2012); Adewuyi et al. (2013); Nkang and Ele (2014) on technical efficiency of cassava showed the average values of technical efficiency level by $77 \%$, $68 \%$ and $70 \%$ respectively, which were lower than Nuabosi cassava farming with multiple cropping and monoculture methods in Randotonda Village.

Table 1. Distribution of technical efficiency level of Nuabosi cassava farmers practicing multiple cropping and monoculture

\begin{tabular}{cccccc}
\hline Range of technical & \multicolumn{2}{c}{ Farmers with monoculture } & \multicolumn{2}{c}{ Farmers with multiple cropping } \\
\cline { 2 - 5 } efficiency level & Frequency & Relative frequency (\%) & Frequency & Relative frequency (\%) \\
\hline Up to 0.70 & - & - & - & - \\
$0.71-0.80$ & 39 & 64 & 5 & 11 \\
$0.81-0.90$ & 22 & 36 & 40 & 87 \\
$0.91-1.00$ & - & - & & 2 \\
\hline Total & 61 & 100 & & 0.8639 \\
\hline Average efficiency level & & 0.7882 & & 0.0400 \\
Standard deviation & & 0.0750 & & 0.7794 \\
Maximum & & 0.8994 & & \\
Minimum & & 0.7084 & &
\end{tabular}


Factors affecting the technical efficiency of Nuabosi cassava farming

The estimation results presented in Table 2 show that the F-statistic value (25.460) is significant at $\alpha 1 \%$. $F_{\text {count }}>F_{\text {table }}(25.460>3.51)$ means that all the variables included in the model simultaneously affect the level of technical efficiency. The age variable has a significant and negative sign. The findings in the field show that $70 \%$ of farmers are at productive age. Maganga (2012); Mussa et al. (2012);
Nahraeni (2012); Okoye et al. (2016) said that with increasing age of farmers, the enthusiasm to be creative and apply new technologies and innovations decreases. Mango et al. (2015) also found that older farmers tend to be technically inefficient because age affects productivity. However, this study is different from the research by Tabe-Ojong and Molua (2017); Tenaye (2020), which conclude that age has a significant effect on technical efficiency and is positive.

Table 2. Factors affecting the technical efficiency of Nuabosi cassava farming with monoculture and multiple cropping methods

\begin{tabular}{lccr}
\hline \multicolumn{1}{c}{ Variable } & Coefficient & Standard error & $t$-ratio \\
\hline Constanta $\left(\mathrm{Z}_{0}\right)$ & $\left.0.771^{* * *}\right)$ & 0.038 & 20.191 \\
Age $\left(\mathrm{Z}_{1}\right)$ & $-0.001^{* * *)}$ & 0.001 & -2.429 \\
Length of farming $\left(\mathrm{Z}_{2}\right)$ & $0.003^{* *}$ & 0.002 & 1.542 \\
Frequency of getting information $\left(\mathrm{Z}_{3}\right)$ & $0.003^{* *)}$ & 0.001 & 1.782 \\
Dummy of farmer group membership $\left(\mathrm{Z}_{4}\right)$ & $\left.0.051^{* * *}\right)$ & 0.014 & 3.701 \\
Cropping pattern dummy $\left(\mathrm{Z}_{5}\right)$ & $0.049^{* * *)}$ & 0.010 & 5.092 \\
\hline
\end{tabular}

$\mathrm{R}^{2}=0.747$, F-statistics $=25.460$

Note: 1. Dependent variable of technical efficiency

2. F table $(\alpha=0.01$, df $1=4, \mathrm{df} 2=103)=3.51$

3. T table $\alpha 0.01=(0.01$, df 99$)=2.36$

$\mathrm{T}$ table $\alpha 0.05=(0.05, \mathrm{df} 95)=1.66$

$\mathrm{T}$ table $\alpha 0.10=(0.10$, df 90$)=1.29$

$* * *)$ Significant on $\alpha$ by $1 \%$
$* *)$ Significant on $\alpha$ by $5 \%$
*) Significant on $\alpha$ by $10 \%$

that farmer membership in farmer groups will increase technical efficiency. Fadwiwati et al. (2014); Nkang and Ele (2014), concluded that access to extension services in farmer groups rises agricultural production. Findings in the field indicate that $75 \%$ of the farmers are already members of farmer groups.

The dummy variable of the cropping pattern has a significant effect and is positive. This shows that farmers practicing multiple cropping are technically more efficient than farmers implementing monoculture. Abebe (2014) reinforced that the practice of multiple cropping has a positive effect on technical efficiency. Farmers who practice multiple cropping gain higher yields because of better conservation of soil resources. The results of the study also depict that $95 \%$ of the formal education of the intercropping farmers graduated from high school, while only $16 \%$ of monoculture farmers were high-school graduates. Educated farmers are able to take advantage of farmers' social information and communication networks, are able to take advantage of new technologies and combine inputs optimally 
Table 4. Distribution of EA level of Nuabosi cassava farmers practicing multiple cropping and monoculture methods

\begin{tabular}{ccccc}
\hline \multirow{2}{*}{ Range of EA } & \multicolumn{2}{c}{ Farmers practicing monoculture } & \multicolumn{2}{c}{ Farmers practicing multiple cropping } \\
\cline { 2 - 5 } & Frequency & Relative frequency $(\%)$ & Frequency & Relative frequency $(\%)$ \\
\hline $0.30-0.39$ & - & - & - & - \\
$0.40-0.49$ & - & - & - & - \\
$0.50-0.59$ & - & - & - & - \\
$0.60-0.69$ & - & 48 & - & - \\
$0.70-0.79$ & 29 & 52 & 42 & 91 \\
$0.80-0.89$ & 32 & - & 4 & 9 \\
$0.90-0.99$ & - & 100 & & 0.8259 \\
Total & 61 & 0.7909 & & 0.0365 \\
\hline Average efficiency level & & 0.0638 & & 0.9042 \\
Standard deviation & & 0.8921 & & 0.8001 \\
Maximum & & 0.7001 &
\end{tabular}

The average value of EA of farmers with monoculture was 0.7909 . This value implies that the average minimum cost level achieved by farmers was $79.09 \%$ of the limit cost. If farmers with Nuabosi cassava monoculture are able to achieve the most efficient cost level, they can get an additional profit of $11 \%$ [1- (0.79/0.89)]. The most inefficient farmers are possible to increase profit by $21 \%$, [1- (0.70/0.89)], with the hope that these farmers can combine a number of inputs at the input price and the amount of output such as farmers with the highest cost efficiency.

Maurice et al. (2015); Onubuogu and Esiobu (2019) reported that the study on food crop and cassava farmers in Nigeria showed the average EA of 0.84 and 0.86 . These EA values were greater than that found in the research in Randotonda Village, for both farmers with monoculture system and the multiple cropping of cassava and peanuts. The difference in EA between farmers applying multiple cropping and monoculture is due to the fact that intercropping farmers have easier access to information on prices for agricultural inputs and outputs, are active in farmer groups and have vehicles to facilitate the transportation of agricultural inputs and products.

\section{Factors affecting the EA of Nuabosi cassava farming}

The data presented in Table 5 highlight the F-statistics value of 18.075 , value of $F_{\text {count }}>F_{\text {table }}$ $(18.075>3.51)$. It means that all variables included in the model simultaneously affect the EA level. The regression coefficient for the age variable has a significant effect and is negative. This suggests that the older the farmer is, the lower the EA will be. Older farmers rely more on experience but are slow to adapt to newer and more efficient practices. This study differs from the research conducted by Girei et al. (2016), which found that with increasing age, EA increases and older farmers tend to have more experience in farming. The length of the farming, which is called experience, has a significant effect and is positive. It is said that the longer the farmer experience in farming is, the more efficient he is in using production inputs. This supports the findings of the studies by Haile (2015) and Mokgalabone (2015), where experienced farmers have higher efficiency since they have a better knowledge of the market situation.

The frequency of getting information has significant effect and is positive, which means that information obtained by the farmers can increase the EA. The information deals with the availability as well as price and quality of agricultural inputs. The variable of farmer group membership has a significant effect and is positive, suggesting that when more farmers become the farmer group members, the EA will increase. This outcome is in line with that found by Audu et al. (2013), but differs from that of Dogba et al. (2020), where EA can be reduced when a farmer wants to be a member of a farmer group. This occurs due to the poor management of the farmer group because the members who want to obtain various information must pay the other group members. 
Table 5. Factors affecting the EA of Nuabosi cassava farming practicing monoculture and multiple cropping methods

\begin{tabular}{lccr}
\hline \multicolumn{1}{c}{ Variable } & Coefficient & Standard error & t-ratio \\
\hline Constanta $\left(\mathrm{Z}_{0}\right)$ & $0.722^{* * *)}$ & 0.039 & 18.652 \\
Age $\left(\mathrm{Z}_{1}\right)$ & $\left.-0.001^{* *}\right)$ & 0.001 & -1.711 \\
Length of farming $\left(\mathrm{Z}_{2}\right)$ & $\left.0.003^{* *}\right)$ & 0.002 & 1.825 \\
Frequency of getting information $\left(\mathrm{Z}_{3}\right)$ & $0.003^{* * *}$ & 0.002 & 1.683 \\
Dummy of farmer group membership $\left(\mathrm{Z}_{4}\right)$ & $\left.0.067^{* * *}\right)$ & 0.015 & 4.552 \\
Cropping pattern dummy $\left(\mathrm{Z}_{5}\right)$ & $0.026^{* * *)}$ & 0.011 & 2.436 \\
\hline
\end{tabular}

$\mathrm{R}^{2}=0.687$, F-statistics $=18.075$

Note: 1. Dependent variable of technical efficiency

2. $\mathrm{F}$ table $(\alpha=0.01$, df $1=4$, df $2=103)=3.51$

3. T table $\alpha 0.01=(0.01$, df 99$)=2.36$

$\mathrm{T}$ table $\alpha 0.05=(0.05, \mathrm{df} 95)=1.66$

$\mathrm{T}$ table $\alpha 0.10=(0.10$, df 90$)=1.29$

***) Significant on $\alpha$ by $1 \%$
$* *)$ Significant on $\alpha$ by $5 \%$
*) Significant on $\alpha$ by $10 \%$

research of Mutoko et al. (2015), which figured out that farmers who get higher education tend to leave the agriculture to non-agricultural activities to earn higher income.

\section{Effect of monoculture and multiple cropping on economic efficiency}

The data in Table 6 uncover that the average level of economic efficiency of monoculture farmers was 0.6233 , which was lower than the efficiency of farmers implementing multiple cropping patterns, with 0.7133 . This difference is due to the implementation of multiple cropping technology so that the soil becomes fertile, the attack of pests is reduced and most multiple cropping farmers have access to input and output markets. and efficiently. This research differs from the

Table 6. Distribution of economic efficiency level of Nuabosi cassava farmers practicing multiple cropping and monoculture methods

\begin{tabular}{|c|c|c|c|c|}
\hline \multirow{2}{*}{ Range of EA } & \multicolumn{2}{|c|}{ Farmers practicing monoculture } & \multicolumn{2}{|c|}{ Farmers practicing multiple cropping } \\
\hline & Frequency & Relative frequency $(\%)$ & Frequency & Relative frequency (\%) \\
\hline $0.30-0.39$ & - & - & - & - \\
\hline $0.40-0.49$ & 1 & 2 & - & - \\
\hline $0.50-0.59$ & 19 & 31 & - & - \\
\hline $0.60-0.69$ & 33 & 54 & 16 & 35 \\
\hline $0.70-0.79$ & 8 & 13 & 27 & 59 \\
\hline $0.80-0.89$ & - & - & 3 & 6 \\
\hline $0.90-0.99$ & - & - & - & - \\
\hline Total & 61 & 100 & 46 & 100 \\
\hline Average efficiency level & & 0.6233 & & 0.7133 \\
\hline Standard deviation & & 0.0674 & & 0.0417 \\
\hline Maximum & & 0.7979 & & 0.8073 \\
\hline Minimum & & 0.4967 & & 0.6260 \\
\hline
\end{tabular}

The economic efficiency estimated in this study is greater than that measured in the examination conducted by Akpan et al. (2013) on cassava farmers in Nigeria, where the average 
level of economic efficiency obtained is 0.5801 , but smaller than the finding of research by Nwike et al. (2017) on cassava in Southeast Nigeria, amounting to 0.76 . If the average monoculture farmers are able to achieve the highest level of economic efficiency, they can save cost by $22 \%$, [1- (0.6233/0.7979)] and the most inefficient farmer will be able to save cost by $38 \%$ [1$(0.4967 / 0.7979)]$, with the hope that the farmers can achieve the highest economic efficiency level. Farmers applying multiple cropping patterns can save cost by $12 \%,[(1-(0.7133 / 0.8073)]$, if they achieve the highest economic efficiency level. Meanwhile, the least efficient farmers are able to save cost by $22 \%$, [1- (0.6260/0.8073)].

\section{Factors affecting economic efficiency of Nuabosi cassava farming}

The data in Table 7 demonstrate that the Fstatistic value was 23.112, significant at $\alpha 1 \%$, with the value of $F_{\text {count }}>F_{\text {table }}(23.112>3.51)$. It can be interpreted that all variables comprised in the model together affect the economic efficiency level. The regression coefficient of age variable has a significant effect on economic efficiency and is negative, meaning that as the farmers get older, the efficiency level decreases. This fact is consistent with a research conducted by Ayodele et al. (2012), where older farmers are less likely to adopt better practices. The length of farming has a significant effect and has a positive relationship, where the farmer's experience in running farming activities is longer, the economic efficiency is increasing. Adeyemo et al. (2010); Ogunleye et al. (2014); Abdul-kareem and Şahinli (2018) said that farming experience increases the efficiency and profitability of cassava.

The frequency of getting information positively influences the economic efficiency. If the quality of information obtained by farmers, in terms of cassava cultivation technology, input and output prices is better, the economic efficiency of each farmer will increase. The dummy variable of farmer group membership has a significant effect and is positive. This means that by becoming a farmer group member, the economic efficiency per farmer increases. Lema (2013) and Mutoko et al. (2015) found that by becoming a farmer group member, farmers obtains information from the field extension officers about distributors, prices, as well as agricultural inputs and outputs. This finding differs from that in the research by Lanamana (2019), where farmer group membership does not put effect on the economic efficiency, due to the fact that many respondent farmers are not yet farmer group members. The dummy variable of cropping pattern has a significant effect and a positive relationship characteristic and this fact illustrates that multiple cropping farmers are economically more efficient in managing cassava farming when compared to monoculture farmers. Nyi et al. (2014) found that cassava planted at the same time as peanuts has increased the net profit.

Table 7. Factors affecting the economic efficiency of Nuabosi cassava farming with monoculture and multiple cropping methods

\begin{tabular}{lccc}
\hline \multicolumn{1}{c}{ Variable } & Coefficient & Standard error & $t$-ratio \\
\hline Constanta $\left(\mathrm{Z}_{0}\right)$ & $0.631^{* * * *}$ & 0.041 & 15.328 \\
Age $\left(\mathrm{Z}_{1}\right)$ & $-0.002^{* * *)}$ & 0.001 & -2.758 \\
Length of farming $\left(\mathrm{Z}_{2}\right)$ & $0.003^{* *)}$ & 0.002 & 1.764 \\
Frequency of getting information $\left(\mathrm{Z}_{3}\right)$ & $0.003^{* *)}$ & 0.002 & 1.751 \\
Dummy of farmer group membership $\left(\mathrm{Z}_{4}\right)$ & $\left.0.033^{* * *}\right)$ & 0.016 & 2.063 \\
Cropping pattern dummy $\left(\mathrm{Z}_{5}\right)$ & $\left.0.001^{* * *}\right)$ & 0.012 & 5.231 \\
\hline
\end{tabular}

$\mathrm{R}^{2}=0.730$, F-statistics $=23.112$

Note: 1. Dependent variable of technical efficiency

2. F table $(\alpha=0.01$, df $1=4$, df $2=103)=3.51$

3. T table $\alpha 0.01=(0.01$, df 99$)=2.36$

T table $\alpha 0.05=(0.05, \mathrm{df} 95)=1.66$

$\mathrm{T}$ table $\alpha 0.10=(0.10, \mathrm{df} 90)=1.29$

\footnotetext{
***) Significant on $\alpha$ by $1 \%$

**) Significant on $\alpha$ by $5 \%$

*) Significant on $\alpha$ by $10 \%$
}

\section{CONCLUSIONS}

The average levels of technical, allocative and economic efficiency of farmers with monoculture

cropping patterns is $78 \%, 79 \%$ and $62 \%$, respectively. These percentages are lower than those of farmers practicing multiple cropping patterns, the average percentage of $86 \%, 82 \%$ and 
$71 \%$ for each efficiency level, correspondingly. The results show that the factors, which have a positive effect on technical, allocative and economic efficiency, are age, length of farming, frequency of getting information, dummy of farmer group membership and cropping patterns dummy. Nuabosi's cassava farmers require assistance from field extension officers in multiple cropping patterns and use of agricultural waste as organic fertilizer.

\section{ACKNOWLEDGMENTS}

The authors would like to express our gratitude to the Rector of Universitas Flores for granting financial support for this research. We also thank Prof. Dr. Ir. Nuhfil Hanani., M.S., Faculty of Agriculture, Brawijaya University, Malang, for providing training in using Frontier Version 4.1 software to facilitate data analysis.

\section{REFERENCES}

Abdulai, S., Nkegbe, P. K., \& Donkoh, S. A. (2013). Technical efficiency of maize production in Northern Ghana. African Journal of Agricultural Research, 8(43), 5251-5259. Retrieved from https://academic journals.org/journal/AJAR/article-stat/FA94C B741671

Abebe, G. G. (2014). Off-farm income and technical efficiency of smallholder farmers in Ethiopia-a stochastic frontier analysis. Master's Thesis 30 Hec Advanced Level. European Erasmus Mundus Master Program: Agricultural Food and Environmental Policy Analysis (AFEPA), 862, 1-53. Retrieved from https://stud.epsilon.slu.se/7004/1/Abebe_G_G _140710.pdf

Abdul-kareem, M. M., \& Şahinli, M. A. (2018). Demographic and socio-economic characteristics of cassava farmers influencing output levels in the savannah zone of Northern Ghana. African Journal of Agricultural Research, 13(4), 189-195. https://doi.org/ 10.5897/ajar2017.12268

Adem, M., \& Gebregziabher, K. (2014). The effect of agricultural extension program on technical efficiency of rural farm households evidence from Northern Ethiopia: Stochastic frontier approach. International Researchers, 3(3), 14-31. Retrieved from http://iresearcher.
org/2.\%20IR\%20Template\%20(last\%20editte d).pdf

Adewuyi, S. A., Agbonlahor, M. U., \& Oke, A. (2013). Technical efficiency analysis of cassava farmers in Ogun State Nigeria. International Journal of Agriculture and Food Security, 4(14), 515-522. Retrieved from https://docplayer.net/22841708-Technical-effi ciency-analysis-of-cassava-farmers-in-ogun-st ate-nigeria-by.html

Adeyemo, R., Oke, J., \& Akinola, A. (2010). Economic efficiency of small scale farmers in Ogun State, Nigeria. Tropicultura, 28(2), 8488. Retrieved from https://www.researchgate. net/publication/46378953_Economic_Efficien cy_of_Small_Scale_Farmers_in_Ogun_State_ Nigeria

Ajieh, P. C. (2014). Adoption of improved cassava production and processing technologies in Oshimili North Local Government Area of Delta State, Nigeria. Indian Research Journal of Extension Education, 14(1), 21-25. Retrieved from https://www.researchgate.net/profile/Ajieh_C huks/publication/272459148_Adoption_Of_C assava_Production_Technologies_Among_W omen_Farmers_In_Aniocha_South_Local_Go vernment_Area_Lga_Delta_State_Nigeria/lin $\mathrm{ks} / 5$ ecaac3f458515626cc9d9fb/Adoption-OfCassava-Production-Technologies-Among-W omen-Farmers-In-Aniocha-South-Local-Gove rnment-Area-Lga-Delta-State-Nigeria.pdf

Akpan, S. B., Okon, U. E., Jeiyol, E. N., Nkeme, K. K., \& John, D. E. (2013). Economic efficiency of cassava based farmers in southern wetland region of cross river state, Nigeria: A translog model approach. International Journal of Humanities and Social Science, 3(12), 173-181. Retrieved from http://www.ijhssnet.com/journals/Vol_3 _No_12_Special_Issue_June_2013/20.pdf

Amosun, J. O., \& Aduramigha-Modupe, V. (2016). Influence of groundnut populations on weed suppression in cassava-groundnut systems. Journal of Agricultural Science, 8(5), 72-78. https://doi.org/10.5539/jas.v8n5p72

Asadullah, M. N., \& Rahman, S. (2011). Farm productivity and efficiency in rural Bangladesh: The role of education revisited. Applied Economics, 41(1), 17-33. https://doi. 
org/10.1080/00036840601019125

Audu, S. I., Otitolaiye, J. O., \& Ibitoye, S. J. (2013). A stochastic frontier approach to measurement of cost efficiency in small scale cassava production in Kogi State, Nigeria. European Scientific Journal, 9(9), 114-122. Retrieved from https://eujournal.org/index. php/esj/article/view/910

Ayodele, O. O., Akinola, A. A. \& Owombo, P. T. (2012). Economic efficiency of land improvement techniques among cassava farmers in Kogi State, Nigeria. Journal of Social Sciences Research, 1(5), 154-159. Retrieved from https://www.researchgate.net/ publication/276271606_Economic_Efficiency _of_Land_Improvement_Techniques_among _Cassava_Farmers_in_Kogi_State_Nigeria

BPS - Statistics of Ende Regency. (2016). Produktivitas Ubikayu di kabupaten Ende. BPS Kab. Ende. Retrieved from https://ende kab.bps.go.id/dynamictable/2016/07/22/45/lu as-panen-produktivitas-dan-produksi-tanaman -ubi-kayu-dirinci-per-kecamatan-di-kabupate n-ende-2015.html

BPS. (2018). Produktivitas Ubikayu di Indonesia. BPS. Retrieved from https://www.pertanian. go.id/Data5tahun/TPATAP-2017(pdf)/37-Pro dtvUbikayu.pdf

Chen, P., Song, C., Liu, X. ming, Zhou, L., Yang, H., Zhang, X., Zhou, Y., Du, Q., Pang, T., Fu, Z. dan, Wang, X. chun, Liu, W. guo, Yang, F., Shu, K., Du, J., Liu, J., Yang, W., \& Yong, T. (2019). Yield advantage and nitrogen fate in an additive maize-soybean relay intercropping system. Science of the Total Environment, 657, 987-999. https://doi.org/10.1016/j.scitotenv. 2018.11.376

Chepng'etich, E., Nyamwaro S. O., Bett, E. K., \& Kizito, K. (2015). Factors that influence technical efficiency of sorghum production: A case of small holder sorghum producers in Lower Eastern Kenya. Advances in Agriculture, 2015, 1-11. http://dx.doi.org/ $10.1155 / 2015 / 861919$

Coelli, T. J., Prasada Rao, D. S., O’Donnell, C. J., \& Battese, G. E. (2005). An introduction to efficiency and productivity analysis. Boston, MA: Springer. https://doi.org/10.1007/b136 381
Cohen, M. J., \& Lemma, M. (2011). Agricultural extension services and gender equality, an institutional analysis of four districts in Ethiopia. ESSP II Working Paper 28, pp. 1-31. Retrieved from https://www.ifpri.org/publi cation/agricultural-extension-services-andgender-equality

Dogba, K. B., Oluoch-kosura, W., \& Chumo, C. (2020). Economic efficiency of cassava production in Nimba County, Liberia: An output-oriented approach. International Conference on Precision Agriculture and Food Waste, 2057-2164. Retrieved from https://www.researchgate.net/publication/341 055431_Economic_Efficiency_of_Cassava_P roduction_in_Nimba_County_Li\#: : :text=The refore $\% 2 \mathrm{C} \% 20$ the $\% 20$ study $\% 20$ sought $\% 20$ to ,using $\% 20$ an\%20output $\% 2$ Doriented $\% 20$ appr oach.\&text=Empirical\%20results\%20showed $\% 20$ that $\% 20$ the,mean $\% 20$ revenue $\% 20$ efficie ncy\%20of\% $2012.9 \% 25$.

Fadwiwati, A. Y., Hartoyo, S., Kuncoro, S. U., \& Rusastra, I. W. (2014). Analisis efisiensi teknis, efisiensi alokatif, dan efisiensi ekonomi usahatani jagung berdasarkan varietas di Provinsi Gorontalo. Jurnal Agro Ekonomi, 32(1), 1-12. https://doi.org/10.21082/jae.v32 n1.2014.1-12

FAO, IFAD, \& WFP. (2013). The state of food insecurity in the world the multiple dimensions of food security. The multiple dimensions of food security. Rome, FAO. Retrieved from http://www.fao.org/3/a-i3434e.pdf

Galluzzo, N. (2017). Technical and economic efficiency in some Italian farms: An analysis in two Italian islands. Agricultural Economics Review, 18(2), 30-39. Retrieved from https:// www.eng.auth.gr/mattas/18_2_3.pdf

Girei, A., Maurice, D., \& Onuk, E. (2016). Empirical analysis of allocative efficiency among fadama food crop farmers in Adamawa State, Nigeria. American Journal of Experimental Agriculture, 11(2), 1-7. https:// doi.org/10.9734/ajea/2016/22315

Haile, B. T. (2015). Determinants of technical, allocative and economic efficiencies among onion producing farmers in Kobo District, Amhara, Region, Ethiopia. Journal of Economics and Sustainable Development, 6(3), 8-18. Retrieved from https://www.iiste. 
org/Journals/index.php/JEDS/article/view/199

11

Hongxin, L., Yuan, Z., Liu, R., Xiao, Y., Wang, R., Lyu, F., \& Wang, Z. (2016). Effects of different intercropping modes on growth, yields and economic benefit of cassava and peanut in symbiotic period. Agricultural Science \& Technology, 17(9), 2017-2021. Retrieved from https://search.proquest.com/ openview/9fb309c0e8ed1bd3661c9f0302247 $\mathrm{d} 35 / 1$ ?pq-origsite $=$ gscholar\&cbl $=1596357$

Itam, K. O., Ajah, E. A., Ofem, U. I., \& Abam, O. E. (2015). Technical efficiency analysis of small scale cassava farmers in Cross River State, Nigeria: A Stochastic Production Frontier Approach. Applied Economics and Finance, 2(4), 10-18. https://doi.org/10.11114 /aef.v2i4.1028

Khan, H., \& Saeed, I. (2011). Measurement of technical, allocative and economic efficiency of tomato farms in Northern Pakistan. International Conference on Management, Economics and Social Sciences (ICMESS'2011) Bangkok, 459-468. Retrieved from http://psrcentre.org/images/extraimages/ 36.\%201211541.pdf

Kitila, G., \& Alemu, B. (2014). Analysis of technical efficiency of small holder maize growing farmers of Horo Guduru Wollega Zone, Ethiopia: A Stochastic Frontier Approach. Science, Technology and Arts Research Journal, 3(3), 204-212. https:// doi.org/10.4314/star.v3i3.33

Kusnadi, N., Tinaprilla, N., Susilowati, S. H., \& Purwoto, A. (2011). Analisis efisiensi usahatani padi di beberapa sentra produksi di Indonesia. Jurnal Agro Ekonomi, 29(1), 2547. http://dx.doi.org/10.21082/jae.v29n1.2011 $.25-48$

Lanamana, W. (2019). Measurement of economic efficiency of upland rice farming in different land ownership status in Mausambi Village, Maurole, Sub-District, Ende Regency. Jurnal AGRISEP, 18(2), 387-402. https://doi.org/ 10.31186/agrisep.18.2.387-402

Latruffe, L., \& Nauges, C. (2014). Technical efficiency and conversion to organic farming: The case of France. European Review of Agricultural Economics, 41(2), 227-253. https://doi.org/10.1093/ erae/jbt024

Lema, H. T. (2013). Comparison of economic efficiency of organic and conventional coffee farming systems in Moshi Rural District, Tanzania [Thesis]. University of Nairobi Kenya. Retrieved from http://erepository. uonbi.ac.ke/handle/11295/56291

Li, Y. H., Shi, D. Y., Li, G. H., Zhao, B., Zhang, J. W., Liu, P., Ren, B., \& Dong, S. T. (2019). Maize/peanut intercropping increases photosynthetic characteristics, 13cphotosynthate distribution, and grain yield of summer maize. Journal of Integrative Agriculture, 18(10), 2219-2229. https://doi. org/10.1016/S2095-3119(19)62616-X

Maganga, A. M. (2012). Technical efficiency and its determinants in irish potato production: evidence from Dedza District, Central Malawi. African Journal of Agricultural Research, 7(12), 1794-1799. Retrieved from https:// academicjournals.org/app/webroot/article/arti cle1381479192_Maganga.pdf

Mango, N., Makate, C., Hanyani-Mlambo, B., Siziba, S., \& Lundy, M. (2015). A stochastic frontier analysis of technical efficiency in smallholder maize production in Zimbabwe: The Post-Fast-Track Land Reform Outlook. Cogent Economics and Finance, 3(1), 1117189. https://doi.org/10.1080/23322039.2 015.1117189

Maurice, D., Adamu, Y., \& Joseph, M. (2015). Analysis of cost efficiency in food crop production among small-scale farmers in Adamawa state, Nigeria. Global Journal of Agricultural Sciences, 14(1), 17-25. https:// doi.org/10.4314/gjass.v14i1.3

Mokgalabone, M. S. (2015). Analyzing the technical and allocative efficiency of small scale maize farmers in Tzaneen Municipality of Mopani District: A Cobb-Douglas and Logistic Regression Approach [Thesis]. University of Limpopo. Retrieved from http://ulspace.ul.ac.za/handle/10386/1215

Mussa, E., Obare, G., Bogale, A., \& Simtowe, F. (2012). Analysis of resource use efficiency in smallholder mixed crop-livestock agricultural systems: empirical evidence from the Central Highlands of Ethiopia. Developing Country Studies, 2(9), 30-41. Retrieved from http:// 
www.iiste.org/Journals/index.php/DCS/article /view/2964

Mutoko, M. C., Ritho, C. N., Benhin, J., \& Mbatia, O. L. (2015). Technical and allocative efficiency gains from integrated soil fertility management in the maize farming system of Kenya. Journal of Development and Agricultural Economics, 7(4), 143-152. https://doi.org/10.5897/jdae2015.0633

Nahraeni, W. (2012). Efisiensi dan nilai keberlanjutan usahatani sayuran dataran tinggi di Provinsi Jawa Barat [Dissertations]. Library of IPB University. Retrieved from https://repository.ipb.ac.id/handle/123456789/ 61310

Nkang, M. O., \& Ele, I. E. (2014). Technical efficiency of cassava producers in ikom agricultural zone of Cross River State- Nigeria. Quest Journals Journal of Research in Agriculture and Animal Science, 2(10), 9-15. Retrieved from http://www.questjournals.org/ jraas/papers/vol2-issue10/B2100915.pdf

Nwike, M. C., Okoli, T. O., Oghenehogagame, P., \& Ugwumba, C. O. A. (2017). Economic efficiency and returns to scale of cassava production in Southeast Nigeria. International Journal of Agriculture Innovations and Research, 6(1), 108-113. Retrieved from https://ijair.org/administrator/components/co m_jresearch/files/publications/IJAIR_2471_F INAL.pdf

Nyi, T., Mucheru-Muna, M., Shisanya, C., Lodi Lama, J. P., Mutuo, P. K., Pypers, P., \& Vanlauwe, B. (2014). Effect of delayed cassava planting on yields and economic returns of a cassava-groundnut intercrop in the Democratic Republic of Congo. World Journal of Agricultural Research, 2(3), 101108. https://doi.org/10.12691/wjar-2-3-3

Ogundari, K., \& Brümmer, B. (2011). Technical efficiency of nigerian agriculture: A metaregression analysis. Outlook on Agriculture, 40(2), 171-180. https://doi.org/10.5367/oa.20 11.0038

Ogunleye, Sunday, A., Adeyemo, R., Bamireand, A. S., \& Binuiomote, S. O. (2014). Cassava production and technical efficiency in Ayedaade Local Government Area of Osun State, Nigeria. Elixir Agriculture, 71, 24465-
24468. Retrieved from https://www.elixirpu blishers.com/articles/1401513165_71\%20(20 14)\%2024465-24468.pdf

Okoye, B. C., Abass, A., Bachwenkizi, B., Asumugha, G., Alenkhe, B., Ranaivoson, R., Randrianarivelo, R., Rabemanantsoa, N., \& Ralimanana, I. (2016). Differentials in technical efficiency among smallholder cassava farmers in Central Madagascar: A cobb douglas stochastic frontier production approach. Cogent Economics and Finance, 4(1), 1143345. https://doi.org/10.1080/23322 039.2016 .1143345

Onubuogu, G. C., \& Esiobu, N. S. (2019). Determinants of allocative (pricing) efficiency of cassava farms in Imo State, Nigeria. Journal of Agriculture and Food Sciences, 17(2), 8699. https://dx.doi.org/10.4314/jafs.v17i2.8

Orewa, S. I., \& Izekor, O. B. (2012). Technical efficiency analysis of yam production in Edo State: A stochastic frontier approach. International Journal of Development and Sustainability, 1(2), 516-526. Retrieved from http://isdsnet.com/ijds-v1n2-35.pdf

Parel, C. P., Caldito, G. C., Ferrer, P. L., De Cuzman, G. G., Sinsioco, C. S., \& Tan, R. H. (1973). Sampling design and procedures. The Agricultural Development Council 630 Fith Avenue. New York: Agricultural Development Council. Retrieved from http://eprints.icrisat. ac.in/13228/

Ragasa, C., Berhane, G., Tadesse, F., \& Taffesse, A. S. (2013). Gender differences in access to extension services and agricultural productivity. Journal of Agricultural Education and Extension, 19(5), 437468. https://doi.org/10.1080/1389224X.2013. 817343

Rivai, R. S., \& Anugrah, I. S. (2011). Konsep dan implementasi pembangunan pertanian berkelanjutan di Indonesia. Forum Penelitian Agro Ekonomi, 29(1), 13-25. http://dx.doi. org/10.21082/fae.v29n1.2011.13-25

Sasmita, I., Supriyono, \& Nyoto, S. (2014). Effect of corn variety on intercropping with peanut in additive series on growth and yield. Caraka Tani: Journal of Sustainable Agriculture, 29(1), 45-52. https://doi.org/10.20961/caraka tani.v29i1.13312 
Tabe-Ojong, M. P. J., \& Molua, E. L. (2017). Technical efficiency of smallholder tomato production in semi-urban farms in Cameroon: A stochastic frontier production approach. Journal of Management and Sustainability, 7(4), 27-35. https://doi.org/10.5539/jms.v7n4 p27

Tang, X., Zhong, R., Jiang, J., He, L., Huang, Z., Shi, G., Wu, H., Liu, J., Xiong, F., Han, Z., Tang, R., \& He, L. (2020). Cassava/peanut intercropping improves soil quality via rhizospheric microbes increased available nitrogen contents. BMC Biotechnology, 20
(1), 13. https://doi.org/10.1186/s12896-020-00 606-1

Tenaye, A. (2020). Technical efficiency of smallholder agriculture in developing countries: The case of Ethiopia. Economies, 8(2), 1-27. https://doi.org/10.3390/ECONOM IES8020034

Widodo, Y. (2018). Cassava productivity for eradicating hunger and poverty in rural areas of Indonesia. Rural Sustainability Research, 39(334), 32-40. https://doi.org/10.2478/plua2018-0005 